\title{
Accounting Majors' Perceptions Of Future Career Skills: An Exploratory Analysis
}

Abbie Gail Parham, Georgia Southern University, USA

Thomas G. Noland, University of South Alabama, USA

Julia Ann Kelly, Georgia Southern University, USA

\begin{abstract}
Business education is often criticized for its failure to develop lifelong skills. This study examines the opinions of 205 students to determine what skills they deem to be important for their future careers. The study then compares the opinions of accounting students against other business disciplines. The results of the study are mixed for the accounting profession. Many of the skills accounting majors ranked as important for their future were not surprising. However, there was some indication that accounting majors may be suffering from a "silo effect" and are not able to fully grasp how skills learned in other university courses impact their professional success.
\end{abstract}

Keywords: Accounting Education; Critical Career Skills; Silo Effect

\section{INTRODUCTION}

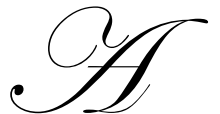

ccounting education is frequently criticized for emphasizing content mastery while ignoring the development of critical skills that rarely become obsolete and are usable and necessary throughout one's career. This manuscript examines the opinions of students to determine what skills they deem to be important for their future careers. This study expands on previous studies by closely examining the relative rankings between accounting majors and other disciplines, specifically to determine if the skills seen as most important by accounting majors are the same skills deemed important by other business students and by accounting and business professionals. The question that this study focuses on is, "Do accounting students recognize the most important skills they will need in their work environment?" Based upon the results of this study, accounting educators will have a better understanding of how faculty may employ pedagogy and content in a manner that will assist students in understanding the importance of these applied skills and help improve these skills to eliminate the perceived deficiencies.

\section{PRIOR RESEARCH}

In a joint effort to examine critical skill development, the American Accounting Association, the American Institute of Certified Public Accountants, and the Institute of Management Accountants joined with the then five national accounting firms to support a project by W. Steve Albrecht and Robert J. Sack (A\&S) that examined the future of accounting education. In their 2000 study, Accounting Education: Charting the Course Through a Perilous Future, A\&S considered content and pedagogy by comparing accounting faculty and accounting practitioner responses. The A\&S study showed that practitioners and faculty included the same skills in the top four, but their ranking varied slightly. Faculty ranked analytical/critical thinking as most important, written and oral communication were ranked second and third, with computing technology being ranked as fourth in importance. Practitioners ranked the top four skills as written communication, analytical/critical thinking, oral communication and computing technology. Foreign language was ranked as the least important skill by both faculty and practitioners (Albrecht, 2000).

In 2003, Francisco expanded upon this study by gathering information from business students on the importance of skills development to their future career. Business students were given a set of identified skills and asked to rank these skills in order of importance to their future careers. The results showed that accounting students' 
rankings were more in line with faculty and practitioners than non-accounting business students. Accounting majors ranked written and oral communication skills as first and second followed by decision making and analytical/critical thinking. Non-accounting business students had a different opinion of the importance of these skills, with decision making as most important followed by oral communications. Leadership and teamwork ousted written communication and analytical/critical thinking in the top four for non-accounting business majors. Foreign language was ranked as least important by all students (Francisco, 2003).

In 2006, the Society for Human Resource Management (the world's largest association devoted to human resource management), along with three other organizations, conducted a study on the readiness of new entrants into the workforce. These groups surveyed more than 400 employers across the United States about the skills needed to succeed in the workforce. The most important skills cited by employers surveyed were professionalism/work ethic, oral and written communications, teamwork/collaboration, and critical thinking/problem solving. This study found that applied skills were viewed as more important than basic knowledge skills. Survey participants believed that college graduates were deficient in many of the applied skills even though the skills were viewed as having a significant impact on the students' ability to compete in the job market. Less than two thirds of respondents ranked four year college graduates as "adequately" prepared for entry level jobs. The percentage of employers ranking knowledge of foreign languages as "very important" was low in comparison with other knowledge and skills; however, more than sixty percent report knowledge of foreign languages as increasingly important for college graduates (SHRM, 2006).

A 2007 report by the Robert Half International Financial Leadership Council stated that accounting professionals can no longer rely on the rules and standards they learned in the past. Increased globalization mandates that accounting professionals learn and apply new skills. Two of the new skills identified in this report include cultural literacy and flexible thinking. Cultural literacy is more than just learning a foreign language. It requires an understanding of the social, political, and business environments in different parts of the world. Flexible thinking is one of the most important skills. Instead of rules, accountants will need to use critical thinking and professional judgment in decision making (Robert Half, 2007).

A study published by Glynn and Wood in 2008 looked at how MBA alumni of Canisius College perceived the importance of nine skills to their professional goals and development and the effectiveness of the curriculum. Critical thinking, problem-solving, presentation, team building, and interpersonal skills were ranked as the top five in importance. Writing was ranked as the least important of the nine skills (Glynn, 2008).

\section{RESEARCH DESIGN}

The research instrument was designed to compare accounting majors' perceptions on the importance of skill development for their future careers against students from other business disciplines. The authors administered a survey instrument to pre-business and business majors currently enrolled in business classes at a regional university. The instrument asked a series of questions about the importance of various skills. Students were asked to rank these skills, on a Likert-type scale from one to five, with one being not important and five being very important, to determine which skills they felt were most important to their future careers.

The 42 skills students were asked to rank had been identified in a previous study in 2003 (Francisco, 2003). The authors then compared the responses between the various groups. The data were then ranked and analyzed to find relevant differences in the responses of the various groups. Statistical analysis was done using analysis of variance (ANOVA) and Bonferroni post-hoc comparisons to identify significant differences between various types of students.

The study sample consisted of students enrolled in different courses in the College of Business Administration at Georgia Southern University. Georgia Southern University, a public university, is located in Statesboro, Georgia, and has an approximate enrollment of 19,000 students. The student population consists of 87.2 percent undergraduate students and 12.8 percent graduate students. Although located in southern Georgia, more than 35 percent of the student body comes from the metro Atlanta region. The average SAT score for incoming freshman is 1,111 out of 1,600 . This compares favorably to both an SAT average of 984 for all Georgia universities and a national average of 1,017 (Georgia Southern University, 2009). 
The College of Business Administration is accredited by AACSB International and the Association to Advance Collegiate Schools of Business International and has more than 3,400 students. The School of Accountancy is one of only 171 accounting schools in the world to earn separate accounting accreditation by AACSB International and has more than 250 junior and senior accounting majors and 81 masters of accountancy students. (AACSB International, 2009)

\section{RESEARCH RESULTS}

The study sample consisted of 205 students. The respondents included pre-business majors, business majors, as well as students majoring in disciplines outside the college of business. Approximately 52 percent of the respondents were male, 79 percent were age 21 or above, and 64 percent were white. Forty-nine percent of the respondents had earned more than 90 hours of academic credit. More than 57 percent of the students had parents with at least a four-year degree while 24 percent of the respondents reported their parents had earned a graduate degree (Table 1).

Table 1: Demographic Information on Survey Participants

\begin{tabular}{|c|c|c|c|c|c|c|}
\hline Gender: & Male & Female & & & & Total \\
\hline & $51.70 \%$ & $48.30 \%$ & & & & $100.00 \%$ \\
\hline \multirow{2}{*}{ Age: } & 17-18 & 19 & 20 & 21 & $21+$ & Total \\
\hline & $1.00 \%$ & $6.90 \%$ & $13.30 \%$ & $28.60 \%$ & $50.20 \%$ & $100.00 \%$ \\
\hline \multirow[t]{2}{*}{ Origin: } & Black & White & Hispanic & Other & $\begin{array}{c}\text { Invalid/No } \\
\text { Response }\end{array}$ & Total \\
\hline & $18.00 \%$ & $64.40 \%$ & $4.90 \%$ & $8.80 \%$ & $3.90 \%$ & $100.00 \%$ \\
\hline \multirow[t]{2}{*}{$\begin{array}{l}\text { Credit Hours } \\
\text { Earned: }\end{array}$} & $0-15$ & $16-30$ & $31-60$ & $61-90$ & $90+$ & Total \\
\hline & $1.50 \%$ & $5.80 \%$ & $9.30 \%$ & $34.10 \%$ & $49.30 \%$ & $100.00 \%$ \\
\hline \multirow[t]{2}{*}{$\begin{array}{l}\text { Parents' } \\
\text { Educational Level: }\end{array}$} & $\begin{array}{c}\text { High School } \\
\text { Diploma }\end{array}$ & $\begin{array}{c}\text { High School } \\
\text { Graduate }\end{array}$ & $\begin{array}{c}\text { Associate } \\
\text { Degree }\end{array}$ & 4 year Degree & $\begin{array}{c}\text { Graduate } \\
\text { Degree }\end{array}$ & Total \\
\hline & $2.90 \%$ & $25.00 \%$ & $14.70 \%$ & $33.40 \%$ & $24.00 \%$ & $100.00 \%$ \\
\hline
\end{tabular}

Forty-six percent of the students in the sample were accounting majors. Seven percent of the respondents were finance or economics majors, four percent were information technology and information systems majors, and 15 percent were management, marketing, or logistics majors. Twenty-seven percent of the students were from disciplines outside the college of business. These disciplines include construction management, sports management, hotel/restaurant management, and public relations (Table 2).

Table 2: Majors of Survey Participants

\begin{tabular}{|l|c|}
\hline Accounting & $46.50 \%$ \\
\hline Finance \& Economics & $7.40 \%$ \\
\hline Information Systems/Information Technology & $3.90 \%$ \\
\hline Management/Marketing/Logistics & $15.20 \%$ \\
\hline Other & $27.00 \%$ \\
\hline Total & $100.00 \%$ \\
\hline
\end{tabular}

\section{TOP NINE RANKED SKILLS FOR ALL MAJORS}

Table 3 shows the respondents' overall ranking of the top nine skills. Each of these nine skills received an overall ranking of four or higher. Motivation and decision making were ranked as the most important skills followed closely by oral communications, professional demeanor, teamwork and leadership. Rounding out the top 
nine skills were written communication, interpersonal skills, and analytical/critical thinking. Accounting majors considered professional demeanor, written communications, motivation, decision making, and oral communication as their top skills (Table 4).

Table 3: Mean Rankings Of Top Nine Skills For All Majors

\begin{tabular}{|l|c|c|c|c|c|c|}
\hline & $\begin{array}{c}\text { Overall } \\
\text { Average } \\
\text { Of Means }\end{array}$ & Accounting & $\begin{array}{c}\text { Finance \& } \\
\text { Economics }\end{array}$ & $\begin{array}{c}\text { Information } \\
\text { Technology/ } \\
\text { Information } \\
\text { Systems }\end{array}$ & $\begin{array}{c}\text { Marketing, } \\
\text { Management } \\
\text { \& Logistics }\end{array}$ & $\begin{array}{c}\text { Other } \\
\text { Disciplines }\end{array}$ \\
\hline Motivation & $\mathbf{4 . 3 8}$ & 4.32 & 4.07 & 4.88 & 4.63 & 4.35 \\
\hline Decision Making & $\mathbf{4 . 3 6}$ & 4.31 & 4.40 & 4.88 & 4.48 & 4.29 \\
\hline Oral Communication & $\mathbf{4 . 3 3}$ & 4.29 & 4.07 & 4.13 & 4.52 & 4.40 \\
\hline Professional Demeanor & $\mathbf{4 . 3 2}$ & 4.41 & 4.33 & 4.63 & 4.45 & 4.02 \\
\hline Teamwork & $\mathbf{4 . 3 1}$ & 4.15 & 4.00 & 4.88 & 4.65 & 4.38 \\
\hline Leadership & $\mathbf{4 . 3 0}$ & 4.20 & 4.13 & 4.50 & 4.68 & 4.28 \\
\hline Written Communication & $\mathbf{4 . 2 2}$ & 4.33 & 4.20 & 4.25 & 4.13 & 4.09 \\
\hline Interpersonal Skills & $\mathbf{4 . 2 2}$ & 4.27 & 4.20 & 4.38 & 4.37 & 4.04 \\
\hline Analytical/Critical Thinking & $\mathbf{4 . 1 3}$ & 4.24 & 4.20 & 4.63 & 4.32 & 3.73 \\
\hline
\end{tabular}

Table 4: Mean Rankings Of Top Nine Skills By Accounting Majors

\begin{tabular}{|l|c|}
\hline \multicolumn{2}{|c|}{ Table 4: Mean Rankings Of Top Nine Skills By Accounting Majors } \\
\hline Professional Demeanor & 4.41 \\
\hline Written Communication & 4.33 \\
\hline Motivation & 4.32 \\
\hline Decision Making & 4.31 \\
\hline Oral Communication & 4.29 \\
\hline Interpersonal Skills & 4.27 \\
\hline Analytical/Critical Thinking & 4.24 \\
\hline Leadership & 4.20 \\
\hline Teamwork & 4.15 \\
\hline
\end{tabular}

The only students ranking any of the top nine overall skills below four were students from other disciplines which gave a 3.73 ranking to analytical/critical thinking skills. One interesting finding among the top nine skills was with written communication. While both males and females ranked written communication high, females ranked this skill at 4.38, significantly higher (at the .05 level) than males at 4.09.

\section{SKILLS RANKED AS UNIMPORTANT FOR ALL MAJORS}

Overall, students ranked only five skills as unimportant (Table 5).

Table 5: Skills Ranked As Unimportant By All Majors

\begin{tabular}{|l|c|c|c|c|c|c|}
\hline & $\begin{array}{c}\text { Overall } \\
\text { Average } \\
\text { of Means }\end{array}$ & Accounting & $\begin{array}{c}\text { Finance \& } \\
\text { Economics }\end{array}$ & $\begin{array}{c}\text { Information } \\
\text { Technology/ } \\
\text { Information } \\
\text { Systems }\end{array}$ & $\begin{array}{c}\text { Marketing, } \\
\text { Management } \\
\text { \& Logistics }\end{array}$ & $\begin{array}{c}\text { Other } \\
\text { Disciplines }\end{array}$ \\
\hline Foreign Language & $\mathbf{2 . 9 2}$ & 2.71 & 2.93 & 3.13 & 3.29 & 3.02 \\
\hline Macro Economics & $\mathbf{2 . 9 3}$ & 2.86 & 3.87 & 2.50 & 3.10 & 2.74 \\
\hline Micro Economics & $\mathbf{2 . 9 6}$ & 2.83 & 4.13 & 2.50 & 3.29 & 2.73 \\
\hline Role Playing & $\mathbf{2 . 9 8}$ & 2.85 & 3.21 & 3.13 & 3.28 & 2.98 \\
\hline Retailing and Sales & $\mathbf{2 . 9 8}$ & 2.34 & 3.53 & 4.13 & 3.94 & 3.22 \\
\hline
\end{tabular}

Any skill with an overall ranking of less than three on the five-point scale was deemed as unimportant. The results are quite shocking. Foreign language skills were ranked as the least important with an overall ranking of 
2.92. Macroeconomics and microeconomics were also ranked as unimportant with overall rankings of 2.93 and 2.96 respectively. The last two skills to receive less than a three ranking were role playing and retailing and sales, both with a 2.98 overall ranking. The overall unfavorable ranking of retailing and sales was driven by the accounting majors who ranked retailing and sales significantly lower than all other student groups. This finding exposes a weakness in most accounting curriculums. Accounting majors do not understand that the practice of public accounting is not only a profession but a business that must generate sufficient profit and cash flows to stay in business. Accounting students must realize that accounting firms should utilize their professional reputation to "sell" their services to attract and keep clients. Additionally, majors who choose career paths other than public accounting also need to recognize that sales are vital to the success of any business.

For students to rank foreign language skills as unimportant in today's global economy was very surprising. Analysis shows that both accounting and finance \& economics majors ranked foreign language below three with accounting majors giving foreign language skills a 2.71 ranking. This finding is hard to fathom given that the School of Accountancy requires each major to take an international accounting course and the recent emphasis on International Financial Reporting Standards (IFRS) throughout the accounting profession.

Another surprising finding is that accounting majors, information technology/systems majors and students from other disciplines ranked both micro and macro economics as unimportant. The recent turbulence in the global economy and the emphasis placed by some professors on the economic down-turn make it appear that students from these majors are still living in the ivory tower and are not yet focused on their future job prospects.

\section{ADDITIONAL FINDINGS}

Other findings of note were on the subject of operations management and change management. Overall, students ranked operations management as slightly important with a ranking of 3.06; however, accounting majors only ranked the subject of operations management at 2.68 (Table 6). This ranking demonstrates that accounting majors do not comprehend the linkage between operations management and cost accounting topics such as overhead allocation, product costing, and inventory valuation. In the area of change management, we found that management/marketing majors (3.87) ranked this significantly higher than accounting majors (3.02). While accounting majors did not rank change management as unimportant, the ranking does demonstrate that management/marketing majors may be more in-tune with the rapid change of business than accounting majors.

Table 6: Skills Ranked As Unimportant By Accounting Majors

\begin{tabular}{|l|l|}
\hline Retailing and Sales & 2.34 \\
\hline Operations Management & 2.68 \\
\hline Human Resource Management & 2.75 \\
\hline Foreign Language & 2.71 \\
\hline Transportation and Logistics & 2.71 \\
\hline Salesmanship & 2.82 \\
\hline Micro Economics & 2.83 \\
\hline Marketing & 2.83 \\
\hline Role Playing & 2.85 \\
\hline Macro Economics & 2.86 \\
\hline
\end{tabular}

Another interesting finding was that accounting majors were the only ones to rank the area of transportation and logistics less than three (2.71). This could mean several things. The first is that most accounting majors do not see themselves working or auditing industries in this field, but it could also mean that they do not understand the importance of the transfer and tracking of goods whether by rail, sea, air, or ground in today's global economy.

Some findings were not surprising. For example, it is unsurprising that accounting majors would rank such skills as managerial accounting, financial accounting, analyzing financial information, and taxes as more important than students from most other business disciplines. Other majors also ranked core competencies in their majors as more important than students outside the discipline. For example, marketing/management majors ranked the skills 
of marketing and human resources management significantly higher than accounting majors. While the finding that marketing/management majors rank human resources management (3.77) higher than accounting majors (2.75) should come as no surprise, it does demonstrate that accounting majors may not realize the importance of the human resource function in hiring employees in both the private and public sectors.

One interesting finding based upon the education level of the custodial parent was the area of customer service (3.81). Even though all student groups ranked customer service as important overall, students whose custodial parent had either a four year degree (4.03) or a graduate degree (3.96) ranked customer service higher than students whose custodial parent either did not graduate from high school (3.68) or was a high school graduate (3.53).

\section{CONCLUSIONS}

The results of this study are mixed for the accounting profession. Many of the skills that accounting majors rank as important for their future are not surprising. Skills such as written and oral communication, motivation, decision making, financial analysis, and professional demeanor are critical for every accountant to be successful.

What is a shock are the skills that accounting majors ranked as unimportant. Accounting majors felt that areas such as foreign languages and micro and macro economics were unimportant. Additional subjects, such as operations management and transportation/logistics, were also rated as unimportant.

The findings that accounting majors are ranking critical functional areas as unimportant leads to the inference that accounting majors may be suffering from a "silo effect." Accounting students are not able to fully grasp how other areas impact the accounting profession whether working in a CPA firm, industry, or government. These results demonstrate that the curriculum of the schools of accountancy needs to be refined. While a major curriculum overhaul may not be necessary, it is apparent that the curriculum will have to include more courses that focus on a variety of business disciplines rather than stand alone business courses based upon the traditional subject matter. If this change is not possible, then accounting professors who teach traditionally based accounting subjects are going to have to do a better job in getting students to understand the impact of other functional areas on the accounting profession.

\section{AUTHOR INFORMATION}

Abbie Gail Parham is an Assistant Professor of Accountancy at Georgia Southern University. Abbie Gail is a Certified Public Accountant and has earned her CMA and CFM certifications. Prior to becoming a member of the accounting faculty at Georgia Southern she was employed as a staff accountant at a CPA firm and as a controller of a large manufacturing company. E-mail: aparham@georgiasouthern.edu

Thomas G. Noland is an Associate Professor in the Mitchell College of Business at the University of South Alabama. Dr. Noland holds professional certifications as a Certified Public Accountant, Certified Management Accountant and Certified Defense Financial Manager. Tom has previously held positions with the Federal Deposit Insurance Corporation and the Securities \& Exchange Commission. He is a retired Lieutenant Colonel from the United States Army Reserve. E-mail: tnoland@usouthal.edu. Corresponding author

Julia Ann Kelly is a retired instructor from Georgia Southern University. Prior to entering academia, Ann worked for over 20 year in real estate as a broker/partner in a commercial and residential real estate company and as director of real property management for the State of Mississippi. E-mail: annkelly@georgiasouthern.edu

\section{REFERENCES}

1. $\quad$ AACSB International (n.d.). Retrieved December 2, 2009, from http://www.aacsb/edu/accreditation/accreditedmembers.asp

2. Francisco, W., Kelly, J., \& Parham, A. G. (2003). Skills development in accounting education: Is everyone on the same page? Business Education Forum, April, 28-31. 
3. Georgia Southern University Fact Book (2009). Retrieved December 2, 2009, from

http://services.georgiasouthern.edu/osra/factbook.htm

4. Glynn, J. G. \& Wood, G. R. (2008). Assessment of critical business skill development by MBA alumni. Journal of College Teaching \& Learning, 5(5), 43-53.

5. Robert Half Finance \& Accounting (n.d.). New-age skills for accounting professionals. Retrieved February 26, 2010, from http://www.ifrs.com/overview/Financial_Management/NewAge_Skills.htm

6. Society for Human Resource Management (SHRM) (2006). Are they ready to work? Employers'

Perspectives on the basic knowledge and applied skills of new entrants to the $21^{\text {st }}$ century U.S. workforce. The Conference Board Report, 1-61. 
NOTES 